\title{
Institutional Traps and Externalities of Sustainable Development of the Mining Country in Transition to Digital and Knowledge Economy
}

\author{
Elena Dotsenko ${ }^{1, *}$, Natalia Ezdina ${ }^{1}$, Dagmar Cagáňová2 ${ }^{2}$ and Svetlana Mudrova ${ }^{1}$ \\ ${ }^{1}$ Plekhanov Russian University of Economics, Department of Political Economy and History of \\ Economic Science, 117997 Moscow, 36 Stremyanny lane, Russia \\ ${ }^{2}$ Slovak University of Technology in Bratislava, 917 24, Jana Bottu 25, Trnava, Slovak Republic
}

\begin{abstract}
The content, boundaries, development vector and expected results of the sustainable development policy today rightfully belong to one of the most debated issues in the scientific community. The imperative of solving the critical problem of replacing the dominant world order based on the extraction of mineral raw materials carries the risk of increasing economic isolationism. This threatens to eliminate the economics of extracting products from technological production chains that meet the needs of modern consumers around the world, and the loss of technological identity of the industry. For the transition of an economy with a developed commodity sector to the path of sustainable development, modernization of industry on a new technological basis is required and saturation of the domestic market with environmentally friendly production requires, on the one hand, the import of technologies, and on the other, significant "environmental technologies connected" investments. Therefore, sustainable development should be both a goal and, at the same time, the result of a new industrialization of the economy, cannot set itself the goal of enhancing isolation from the global raw materials market.
\end{abstract}

\section{Introduction}

With regard to sustainable development, neo-industrialization means the restoration of the links of production chains lost in the 1990s in mechanical engineering, radio electronics, instrumentation, food industry on a new technological basis on the one hand, and on the resource base of the developed raw materials complex on the other. Consequently, the initiation of neo-industrial import substitution means a balance of participation of the Russian economy in the system of sustainable development on the one hand, and the realization of national innovative potential in domestic industry on the other.

However, the separation of state regulation of the economy from the imperative of sustainable development and the low environmental efficiency of the protectionism of raw materials makes us turn to the problem of creating the necessary institutional environment.

\footnotetext{
${ }^{*}$ Corresponding author: ktyf110372@,rambler.ru
} 
Unfortunately, the existing institutions in the investment sphere, in the formation and implementation of industrial policy, in the relations between the Russian state and the social sector, as well as the owners of industrial enterprises impede not only sustainable development, but also the entire neo-industrialization of the economy. On top of this, we can talk about the emergence and ongoing deepening of institutional traps, falling into which, the imperative of the transition to sustainable development risks remaining unfulfilled.

Institutions are stable norms, rules, procedures, well-established ideas that govern the entire social, including economic, life [1-2]. The generally accepted consensus definitions of institutions include the norms of economic behavior and the governing ways of thinking of members of society, the "rules of the game" that define interagency relationships, sustainable socio-economic practices.

Therefore, it is the institutions that are "responsible" for the formation of certain economic strategies, both individual and collective. To initiate the transition to sustainable development, it is important that the necessary institutions were a key condition for its strategic success, as well as the final result of its implementation.

However, the deinstitutionalization of structural policies hinders purposefully and as soon as possible to begin to form the institutions necessary for the transition to sustainable development of both the state and business. It manifests itself in the deformation of the longterm economic interests of the state and the absence of effective industrial development strategies combining the interests of the state, raw materials and manufacturing businesses, large, medium and small enterprises, financial firms and industrial enterprises. Along with this, the deinstitutionalization of the economic policy of the Russian state is strengthened by subjective forces - the raw material lobby, the political interests of maintaining the raw material rental model, the lack of understanding by the authorities of the consequences of environmental degradation of industry and the loss of competitiveness by the subjects of the green economy in the face of lower prices for mineral resources.

The source and, at the same time, the force that destroys the institutional environment of the transition to sustainable development in the Russian economy are its institutional traps. In general terms, they are ineffective, but stable norms, rules, and goals. They consistently worsen the situation in the economy for most groups of its subjects for the sake of some, but they do not resolve for a long time, since the mechanisms of enforcement of ineffective norms (formal or informal) are preserved.

\section{Materials and Methods}

The founders of the theory of institutional traps distinguish two of their root causes.

The first is the hysteresis effect (preservation of ineffective norms after the "shake" of the system, the "attenuation" of disturbances in it) [3]. It can be traced to the preservation of old inefficient institutions after economic reforms, since these institutions are associated with the deep interests of key actors - the state, big business, political parties.

The second reason is the "Nash equilibrium" (ineffective for the majority of strategies of individual economic entities, which give them the only opportunity to maximize their income in response to the actions of others) [4]. It manifests itself, for example, in the conservation of obsolete resource-intensive technologies and the growth of raw material production in the Russian economy, despite the extremely unfavorable dynamics of the global commodity market.

We can supplement the reasons for the formation of institutional traps that the process of transition to sustainable development in the Russian economy fell into with the following. 
Firstly, by the effect of the "learning effect" - increasing the benefits of preserving the economics-inefficient institutions of the economy, as the group interested in them accumulates experience in their use [5]. An example is the desire of raw oligarchic groups to maximize the production of raw materials and their exports and minimal processing, while innovative enterprises do not have any significant lobby in the Russian economy.

Secondly, by the "conjugation effect" - by increasing the stability of ineffective norms due to their interweaving and self-maintenance [6]. An example is the coordinated lobbyism of importers of finished products and exporters of raw materials [7].

Thirdly, the effect of coordination is the increase in costs and losses of economic entities seeking to counteract inefficient norms. This reason for the formation of institutional traps of import substitution is manifested in the high corruption of investment decisions of the state and the distribution of its support among a narrow circle of "influence groups" - commodity companies and associated banks [8].

Fourth, cultural inertia - the reluctance of economic entities to change behavioral patterns that have been effective in the past (such as the state's preference for supporting commodity corporations over small and medium-sized high-tech entrepreneurships).

\section{Results and Discussion}

The set of institutional traps that hinder the initiation of the transition to sustainable development consists of general ones that hinder the development of resource conservation and increase the degree of processing of raw materials in the Russian economy as a whole, and specific one that preserve the dominance of raw material corporations in the national economy.

We refer the following to the general institutional traps of the transition to sustainable development that impede the implementation of not only its economic, technological, but also ecological and social roles:

- a trap of the rent-raw model of the Russian economy, in which the problems of competitiveness, low investment attractiveness, and technological backwardness of the manufacturing sectors of the Russian economy are used by representatives of commodity corporations interested in the dominance of the raw materials sector to effectively realize their interests. Their interests contradict the goals of the transition to sustainable economic development, since they lead to increased dependence of budget revenues and population, macroeconomic indicators on the extraction and export of raw materials. And the transition from a raw material rental to a processing model, which is more dependent on the global technology market than on raw materials, will inevitably violate the interests of the "influence groups" that dominate in the Russian economy. As a result, the likelihood of a new negative structural shift is increasing in the economy, the consequences of which will be much larger and will ultimately undermine the possibility of a transition to sustainable development;

- a trap for the shadow economy (for example, the "negative selection" of taxpayers, when firms - tax evaders are more competitive than companies that are bona fide taxpayers). Corruption is directly connected with it, which makes competitive and funded companies involved in the formation and distribution of administrative ("bureaucratic") rents appropriated by government representatives who make important business decisions. So, according to the results of 2015, the corruption perception index in Russia calculated by the Transparency International International Fund was 2.0 (1 - the highest level of corruption, 10 - the lowest level of corruption), which corresponds to 119 th place in the world. The corruption trap of the Russian economy in the 2010s reinforced by the lack of effective concepts of interaction between the state and business [9]. Thus, neither the mass 
privatization of the 1990s, nor the attraction of the Russian state to the model of oligarchic capitalism of the South Korean model of the 1960-1970s (the so-called "chaebols" "Samsung", "LG Group", "GS Group", "Hyundai”, "SK Group”, "Daewoo") did not justify themselves [10]. The largest domestic commodity state-owned corporations strengthened the role of the country's economy as a global "donor of raw materials", and did not become either technological leaders or major investors in fundamental developments and R\&D, and stateowned banks as key investors and creditors for the massive growth of manufacturing industries;

- a trap of post-privatization development, in which the Russian state is forced to periodically administratively redistribute property rights of companies that are economically and socially ineffective, or politically opportunist. Moreover, the nationalization of oil and gas corporations by the state in the 2000 s did not solve the problem of their economic efficiency and technological modernization. Thus, the unfavorable situation on the world gas market and infrastructure restrictions led to a decrease in PJSC Gazprom's net profit in 2014 by 3.3 times, export - by $18 \%$ [11];

- the trap of high interest rates and low exchange rates of the national currency. To justify the policy of an unprecedentedly high discount rate, which has made bank credit unavailable to most manufacturing enterprises since 2014, the Bank of Russia cites counter currency speculation and curbs the devaluation process. At the same time, the management of the Bank of Russia recognizes capital flight, a high share of imports and a decrease in foreign currency inflows due to unfavorable commodity market conditions as the main factors of the devaluation - the effects of the cumulative effects of other institutional traps;

- the trap of low wages for highly skilled and scientific work, which at a certain stage played the role of a factor in the price competitiveness of Russian industry (mainly in 1992-2002). Subsequently, in the Russian economy, as the world financial and commodity markets improved, the wage gap between those employed in the raw material and processing sectors widened. The reasons for this were the "peak" of the development of the rent-raw material model of the economy, the outstripping wage growth relative to labor productivity, the concentration of income in the segment of financial speculation, a high share of the shadow economy. The most underrated in Russia is the work of scientists. All this is a strong disincentive factor in the accumulation of intellectual capital and the innovative development of industry.

Specific institutional traps that make government efforts to transition to sustainable development ineffective include the following.

The first specific institutional trap of the transition to sustainable development is the low efficiency of public investment spending with a high share of state ownership in the raw material sector. Russian state-owned companies own $45 \%$ of the capital of enterprises in the oil industry, $49 \%$ in the banking sector and $73 \%$ in transportation [12]. At the same time, the capitalization of Russian state-owned companies has been significantly reduced in recent years. So, for 2010-2014 the value of shares of Russian state-owned companies decreased by $\$ 80$ billion [13].

No less dangerous for the government to initiate transition to sustainable development is the technological backwardness of state corporations. So, for 2000-2014 Gazprom invested in oil and gas production and transportation of 3.6 trillion rubles, of which -2.5 trillion ruble in projects that have not reached more than half of their design capacity. In particular, the Sakhalin-Vladivostok gas pipeline is used at 20\%, the development of the Shtokman gas field together with the French group "Total" has been terminated with losses of 22.3 billion rubles [11]. In the field of high technologies, the state corporation Rosnano, established in 2007, remains unprofitable (profit was recorded only in 2014 as a result of the devaluation of the ruble) - with an increase in losses from 18 to 40 billion rubles for 2010-2013. Moreover, for 
2007-2012 the volume of state financing of Rosnano amounted to 259 billion rubles, and expenses - 196 billion rubles (including 47 billion rubles of direct investments in foreign companies) [13]. Many large projects of Rosnano went bankrupt as a result of the technological lag of their products from the requirements of the global innovation market: "Nitol" (solar panels - 9.4 billion rubles), "Cutting Edge" (silicon wafer components - 2.6 billion rubles), "Plastic Logic" (flexible tablet computers - 3.1 billion rubles), "Liotech" (production of lithium batteries, 13.5 billion rubles) [14].

The second specific institutional trap of the transition to sustainable development is to preserve the low level of market institutions in the raw material rental model of the economy. Underdeveloped market institutions inhibit the growth of entrepreneurial activity and deprive efficient state support of manufacturing and high-tech industries in which Russian state investments have proved to be ineffective. Market institutions formed in Russia during the reform period - external (government bodies, laws and regulations, courts), as well as internal (contracts, property rights, competition, pricing mechanisms) [15], are at a low level of development, and do not provide full business interaction and power, nor its necessary support [16]. Consequently, the persistence of weak market institutions in the Russian economy is predetermined by the low technological level of the prevailing industries. And the technological backwardness of the Russian economy itself is largely due to weak market institutions [17].

The third specific trap of the transition to sustainable development is negative institutional externalities. They represent the undesirable consequences of the functioning of institutions specially created to initiate this process. And in order to overcome these consequences, in turn, the creation of new institutions is required; in the future, such a cycle of "institutioncreation" can be repeated many times.

All institutional traps of the transition to sustainable development, both general and specific, are closely linked to the problem of the technological lag of the Russian economy. As a result, a special trap is formed - the technological one. It represents a stable, selfsustaining situation in which the development of competitive high-tech industries in Russia for import substitution is constrained by an unfavorable institutional environment.

The technological trap leads to the fact that enterprises continue to adhere to old, more resource-intensive technologies, even in the presence of significant demand for domestic industrial products and the growth in demand for ecological goods.

Therefore, today the Russian state faces the most difficult task of creating the institutional conditions for the transition to sustainable development. It is extremely difficult to ignore the need for its initiation, since it is an objective response to a critical imbalance between the environmental consequences of production and consumption. But the transition to sustainable development is constrained by deep institutional traps, and attempts to develop a competitive, internally-oriented output of consumer goods and means of production are accompanied by significant institutional externalities.

\section{Conclusion}

Thus, the lack of necessary transformations of interactions between the state and market entities has led to the formation of a complex of institutional traps in the reforming Russian economy - negative sustainable norms and rules that hinder the transition to sustainable development. These traps nullify the state's attempts to stimulate this process and are associated with the preservation of its raw material rental model, with the growth of resource consumption, with the preservation of distrust of the state and the low efficiency of its administration in the environmental management system, with specific externalities. To exit 
the transition to sustainable development from the existing institutional traps, the formation of market and state institutions is required that are associated with targeted programming of this process, with the development of the legislative framework, the contractual basis for relations between producers of raw materials, intermediate and finished products, R\&D, which can reduce the transaction costs of starting a transition to sustainable development.

\section{Acknowledgement}

The reported study was funded by the grant "The mechanism of consolidation of the principles of knowledge and digital economy to ensure an increase in entrepreneurial culture and reduce interregional differences in the level and quality of life of the population in accordance with the main directions of the spatial development strategy of the Russian Federation until 2025".

\section{References}

1. D. North, Am. Econ. Rev., 55:1), 86-91 (1965)

2. O. E. Williamson, The Nature of the Firm (Oxford University Press, New York, 1991)

3. E. Colson, Tradition and Contract: The Problem of Order (Adeline Publishing, Chicago, 1974)

4. J. Nash, Proc. Nat. Ac. Sci., 36:1, 48-49 (1950)

5. A. O'Sullivan, S.M. Sheffrin, Economics: Principles in Action (Pearson Prentice Hall, New Jersey, 2003)

6. A. Gobbi, G. Frenking, J. Am. Chem. Soc., 116:20, 9275-9286 (1994)

7. S. Zhironkin, D. Khloptsov, N. Skrylnikova, I. Petinenko, O. Zhironkina, E3S Web Conf., 41, 04010 (2018)

8. S.A. Zhironkin, Ugol', 4, 29-31 (2001)

9. N. V. Kudrevatykh, A. A. Galler, Economics and Innovation Management, 1, 45-54 (2019) DOI: 10.26730/2587-5574-2019-1-45-54

10. S. Zhironkin, M. Gasanov, G. Barysheva, K. Kolotov, O. Zhironkina, E3S Web Conf., 15, 03012 (2017)

11. V. Frolova, O. Dolina, T. Shpilkina, E3S Web of Conf., 105. 01054. (2019)

12. M. Anastasov, N. Kazitskaya, I. Politkovskaya, E3S Web of Conf., 105. 04043. (2019)

13. O. Borisova, V. Frolova, L. Artamonova, E3S Web of Conf., 105. 04047. (2019)

14. O. Miliushenko, A. Kovalev, M. Zhidkova, E3S Web of Conf., 105. 04046. (2019)

15. O. Ivanenko, E3S Web of Conf., 105. 04025. (2019)

16. Shavina E., Fisunov S., E3S Web of Conferences 105, 04018 (2019)

17. O. Kalenov, S. Kukushkin, R. Kamanina, E3S Web Conf., 105, 04028 (2019)

18. S. Kukushkin, O.Kalenov, E3S Web Conf., 105, 04022 (2019)

19. Kalenov, O., Shavina, E. , E3S Web of Conferences 41, 04054 (2018)

20. M. Cehlár, J. Janočko, Z. Šimková, T. Pavlik, M. Tyulenev, S. Zhironkin, M. Gasanov, Resources, 8:1, 21 (2019) 
21. T. V. Kiseleva, V. G. Mikhailov, Ya. S. Mikhailova, Economics and Innovation Management, 3, 62-68 (2019) DOI: 10.26730/2587-5574-2019-3-62-68

22. E. A. Gasanov, Economics and Innovation Management, 2, 39-49 (2019) DOI: 10.26730/2587-5574-2019-2-39-49

23. S. K. Demchenko, M. S. Zlotnikov, T. A. Melnikova, O. S. Demchenko, International Journal of Civil Engineering and Technology, 10:2, 1877-1884 (2019)

24. M. S. Zlotnikov, V. V. Telnykh, S. I. Mutovin, S. K. Demchenko, J. J. Suslova, Journal of Environmental Management and Tourism, 8:2, 366-372 (2017)

25. S. K. Demchenko, J. J. Suslova, A. S. Yamschikov, I.R. Ruyga, T.A. Melnikova, Journal of Applied Economic Sciences, 12:1, 194-205 (2017) 